\title{
Responses of the maize plant to chromium stress with reference to antioxidation activity
}

\section{Saborni Maiti ${ }^{1}$, Nirmalia Ghosh ${ }^{1}$, Chiranjib Mandal' ${ }^{1}$ Kingsuk Das ${ }^{1}$, Narottam Dey $^{2}$ and Malay Kumar Adak*}

\author{
'Department of Botany, Plant Physiology and Plant Molecular Biology Research Unit, University of Kalyani, \\ Kalyani, 741235, India. \\ 2Department of Biotechnology, Visva-bharati University, Shantiniketan, 731235, India. \\ *Corresponding author: mkadak09@gmail.com
}

Received: 5 July 2012; Accepted: 5 November 2012

\begin{abstract}
Two maize varieties, viz. Sartaj and Deccan, have been evaluated according to their responses to chromium (Cr) in terms of specific physiological and biochemical attributes. During the exposure to $\mathrm{Cr}$ concentration $(0,50,100,200$ and $300 \mu \mathrm{M})$ of potassium dichromate $\left(\mathrm{K}_{2} \mathrm{Cr}_{2} \mathrm{O}_{7}\right)$ for seven days, significant changes of oxidative stress in terms of lipid peroxidation and protein oxidation were recorded along with other antioxidative pathways. It is revealed that irrespective of varieties, Sartaj was more prone to oxidative stress since the amount of superoxide due to $\mathrm{Cr}$ exposure was found to be significant, unlike the second variety, Deccan. In addition, for Sartaj the activity of NAD(P)H oxidase recorded a significant linear increase in a dose response manner.The changes of antioxidative enzymes recorded significant variation in both varieties under stress compared to control. However, Deccan maintains a consistent up regulation in SOD and GPX activities. Contrarily, APX activity was less sensitive to both varieties. The activation of antioxidative mechanisms due to the impact of $\mathrm{Cr}$-induced oxidative stress has been described subsequently. The results deriving from this investigation might be effective for the selection of tolerant plant types under chromium contamination.
\end{abstract}

Keywords: antioxidative enzymes, MDA, protein oxidation, ROS.

Abbreviations: APX: Ascorbate peroxidase, AsA: Ascorbic acid, CAT: Catalase, DTT: Dithiothreitol, DNPH: Dinitrophenylhydrazine, GPX: Guaiacol peroxidase, MDA: Malondialdehyde, PMSF: Phenylmercuric sulfonyl fluoride, PVP: Polyvinylpyrrolidone, PVPP: Polyvinylpolypyrrolidone, ROS: Reactive Oxygen Species, SOD: Superoxide dismutase.

\section{INTRODUCTION}

Chromium $(\mathrm{Cr})$ is the 21 st most abundant element in the Earth's crust with an average concentration of $100 \mathrm{ppm}$ (Emsley, 2001). It is a transition metal located in group VI B of the periodic table. Mainly due to tanning and chrome-plating industrial activities, large quantities of $\mathrm{Cr}$ compounds are discharged as liquid, solid and gas waste into the environment, and ultimately have significant adverse biological and ecologic effects (Kotas and Stasicka, 2000). Cr occurs in the environment especially in two valence states: trivalent $\mathrm{Cr}$ [ $\mathrm{Cr}$ (III)] and hexavalent $\mathrm{Cr}[\mathrm{Cr}(\mathrm{VI})]$. These two forms display quite different chemical properties in terms of mobility, bioavailability and toxicity (Panda and Choudhury, 2005). Of these two forms, $\mathrm{Cr}$ (VI) shows more phytotoxicity when absorbed by plants (Panda, 2007). Cr interferes with several metabolic processes and its toxicity to plants is exhibited by reducing seed germination, stunted seedling and inadequate accumulation of phytomass. Subsequently, this aggravates the further degradation of pigments, stunting and, finally, plant death (Vajpayee et 
al., 2000; Gikas and Romanos, 2006; Zou et al., 2006). Being a heavy metal, $\mathrm{Cr}$ is a potential agent of oxidative stress, inducing oxidative damage to lipids, proteins and DNA-like biomolecules (Shanker et al., 2004). Cr changes in activity of antioxidant enzymes as well as of other enzymes in order to disrupt the nutrients and water balance (Pandey and Sharma, 2003). It is also reported that it could stimulate the formation of free radicals and reactive oxygen species (ROS) such as superoxide radicals $\left(\mathrm{O}_{2}^{-}\right)$, hydrogen peroxide $\left(\mathrm{H}_{2} \mathrm{O}_{2}\right)$ and the hydroxyl radical $(\cdot \mathrm{OH})$. Furthermore, under natural growth conditions, plants are adapted to minimize the damages induced by ROS (Jinhua et al., 2009). In response to such abiotic stress, plants are also tuned to mitigate the oxidative stress by number of ways. Nonenzymatic and enzymatic anti-oxidation cascades are common defense mechanisms as upregulated under such metal induced oxidative stress. This defense system is composed of antioxidant enzymes: superoxide dismutase (SOD), peroxidase with different variants (e.g., ascorbate peroxidase, guaiacol peroxidase and glutathione reductase), catalase (CAT). Some other non-enzymatic antioxidant moieties (e.g., ascorbic acid, glutathione, carotenoids, flavonoids, $\alpha$-tocopherol etc.) are also important to quench the ROS developed under such condition (Gratão et al., 2005).

Maize (Zea mays L.), a typical cereal crop of temperate and subtropical zones is displayed as a variable stress tolerant plant under environmental extremities. By dint of the $\mathrm{C}_{4}$ advantages, maize is able to thrive well under the condition of soil moisture deficit coupled with high illumination inducing oxidative stress. Besides, maize plants have been reported to hyperaccumulate a number of heavy metals and $\mathrm{Cr}$ is one of them (Shanker et al., 2005).

Maize varieties have been reported with the illustration of wider adaptability to various abiotic stresses; however, in the present experiment the varieties Sartaj and Deccan have earlier been clarified with its potential for salinity stress (Uma et al., 1990). Since salinity stress is most integrally associated with oxidative damage, the way maize plants are to sensitize under heavy metal stress might be justified to observe. With this background, Deccan and Sartaj were investigated under the condition of heavy metals, e.g. Cr, as in the present case. $\mathrm{Cr}$ has already been mentioned to cause oxidative induction to change the cellular responses in many crop species. Therefore, maize being a potential practiser of $\mathrm{C}_{4}$ photosynthetic pathway, having to overcome the induction of oxidative stress under heavy metal contamination and how these two varieties could be discriminated to accomplish the antioxidation pathway are our focus. The effects of $\mathrm{Cr}$ and subsequent antioxidative responses to different concentrations $(0,50,100,200$ and $300 \mu \mathrm{M})$ applied to two maize varieties (viz, Sartaj and Deccan) are investigated. We describe the effects of different concentrations of $\mathrm{Cr}$ on growth attributes, generation of $\mathrm{O}_{2}-$ and $\mathrm{H}_{2} \mathrm{O}_{2}$, membrane lipid peroxidation, protein carbamylation along with the changes in activities of enzymatic antioxidation pathway, including SOD, guaiacol peroxidase (GPX) and ascorbate peroxidase (APX).

\section{MATERIAL AND METHODS}

Plant culture and chromium treatments: In order to fulfill the aforementioned objectives, an experiment was conducted in the laboratory of Plant Physiology and Plant Molecular Biology, Department of Botany, University of Kalyani, West Bengal, India. Seeds of two maize varieties (namely, Sartaj and Deccan) were collected from Bidhan Chandra Krishi Viswavidyalaya, Mohanpur, West Bengal, India. Seeds were soaked in $0.1 \%$ mercuric chloride $\left(\mathrm{HgCl}_{2}\right)$ for 15 minutes, rinsed twice with distilled water, transferred to Petri dishes and kept for germination at $30^{\circ} \mathrm{C}$ for 5 days. Germinated seedlings (their ages being recorded from the day of radical emergence) of uniform appearance were selected and grown in plastic pots, supplemented with Hoagland's nutrient medium (Hoagland and Arnon, 1950). Afterwards, the seedlings were able to grow for 10 days in the open air in order to attain their full growth under natural conditions at around $30 / 25^{\circ} \mathrm{C}$ during day/night

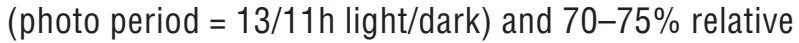
humidity $(\mathrm{RH})$ in the month of March. It is already reported that $\mathrm{Cr}(\mathrm{VI})$ is hexavalent $\mathrm{Cr}$ (in which oxidation state +6 could easily be obtained from any salts of chromate and dichromate). Moreover, chromate of any alkali metal, like $\mathrm{Na}$ or $\mathrm{K}$, when undergoing aqueous solution, releases $\mathrm{Cr}$ (VI) (Zou et al., 2009). Therefore, in the present experiment we used potassium dichromate $\left(\mathrm{K}_{2} \mathrm{Cr}_{2} \mathrm{O}_{7}\right.$, analytical reagent, E-MARK) as a source of $\mathrm{Cr}^{2}(\mathrm{VI})$. From the stock solution of $\mathrm{K}_{2} \mathrm{Cr}_{2} \mathrm{O}_{7}$, a series of dilution $(0,50,100,200$ and $300 \mu \mathrm{M})$ was made in deionized water and supplemented with full strength Hoagland's nutrition solution. Plants were kept at each concentration with ten seedlings for seven days, and thereafter destructive sampling was done. For each experiment, equal amounts of fresh tissues with three replications were taken both from control and treated plants and following parameters were measured under identical laboratory conditions. 
Measurement of growth and biomass: Growth was measured in terms of shoot and root length along with their dry biomass. Shoot and root length were measured following the harvest in fresh samples. For dry biomass, $2 \mathrm{~g}$ of shoot and root tissue for each sample were dried at $80^{\circ} \mathrm{C}$ for $48 \mathrm{~h}$ and made complete dry until constant weights achieved.

Estimation of reactive oxygen species: superoxide and hydrogen peroxide: To detect the generation of $\mathrm{O}_{2}-$, the method was adopted from Elstner and Heupel (1976), with some modification. One gram of leaf sample was thoroughly homogenized with $65 \mathrm{mM}$ phosphate buffer ( $\mathrm{pH} 7.8$ ) and supernatant was saved following centrifugation at $5,000 \mathrm{~g}_{\mathrm{n}}$, for $15 \mathrm{~min}$, at $4^{\circ} \mathrm{C}$. The assay mixture $(2 \mathrm{~mL})$ consisting of $0.9 \mathrm{~mL}$ of $65 \mathrm{mM}$ phosphate buffer ( $\mathrm{pH} 7.8), 0.1 \mathrm{~mL}$ of 10 $\mathrm{mM}$ of hydroxylamine hydrochloride and $1.0 \mathrm{~mL}$ of supernatant was incubated at $25^{\circ} \mathrm{C}$ for 30 minutes. 1 $\mathrm{mL}$ of $17 \mathrm{mM}$ sulphanilamide and $1.0 \mathrm{~mL}$ of $7.0 \mathrm{mM}$ $\alpha$-naphthylamine were added and incubated at $25^{\circ} \mathrm{C}$ for 20 minutes. The changes in absorbance against a reagent blank were recorded spectrophotometrically at $530 \mathrm{~nm}$ and generated $\mathrm{O}_{2}{ }^{-}$was calculated from a standard curve of nitrite salt.

$\mathrm{H}_{2} \mathrm{O}_{2}$ content was determined (Sun et al., 2006). Approximately $1.0 \mathrm{~g}$ leaf sample was crushed with liquid nitrogen followed by extraction of $0.1 \%(\mathrm{w} / \mathrm{v})$ TCA. The supernatant was centrifuged at $12,000 g_{n}$ for 20 minutes at $4^{\circ} \mathrm{C}$. The assay mixture (consisting of $0.5 \mathrm{~mL}$ supernatant, $1 \mathrm{~mL}$ of $1.0 \mathrm{M} \mathrm{KI}$ and $0.5 \mathrm{~mL}$ of $10 \mathrm{mM}$ potassium phosphate buffer, pH 7.0) was prepared. The absorbance of supernatant was read at $390 \mathrm{~nm}$. The content of $\mathrm{H}_{2} \mathrm{O}_{2}$ was calculated from a standard curve.

Lipid peroxidation: For the lipid peroxidation, malondialdehyde (MDA) content was determined. Leaf homogenate was extracted with $20 \%(\mathrm{w} / \mathrm{v})$ trichloroacetic acid (TCA) containing $0.5 \%$ (w/v) thiobarbituric acid (TBA). MDA content was determined by reading the absorbance at $532 \mathrm{~nm}$ and corrected for nonspecific absorbance at 600 nm (Heath and Packer, 1968).

Protein oxidation assay: For protein oxidation, protein carbonyl content was determined. It was measured by the reaction with di-nitro-phenyl-hydrazine (DNPH) (Verbeke et al., 2000). The leaf homogenate was extracted with $6 \%$ $(w / v)$ SDS followed by 25 minutes incubation at room temperature $\left(4^{\circ} \mathrm{C}\right)$. Afterwards, $10 \mathrm{mM}$ DNPH in $10 \%$ TCA, being incubated with gentle shaking for 40 minutes. Precipitation of protein was done by $15 \%$ (w/v) TCA on ice for $15 \mathrm{~min}$. The samples were centrifuged at 10,000 $g_{\mathrm{n}}$ and pellets were washed twice with $20 \%$ (w/v) TCA. Finally, the protein pellets were resuspended in $0.2 \mathrm{M}$ sodium phosphate buffer $(\mathrm{pH} 7.0)$ and the absorbance was measured at $360 \mathrm{~nm}$.

Determination of the NAD(P)H oxidase activity: Leaf homogenate was extracted by $50 \mathrm{mM}$ potassium phosphate buffer ( $\mathrm{pH} 7.0$ ) and centrifuged at $10,000 \mathrm{~g}_{\mathrm{n}}$ at $4^{\circ} \mathrm{C}$ for 20 minutes (Smiri et al., 2010). Finally, NAD(P) H oxidase activity was determined in an assay mixture containing $100 \mathrm{mM}$ sodium acetate (pH 6.5), $1 \mathrm{mM} \mathrm{MnCl}$, $0.5 \mathrm{mM} \mathrm{p}$-coumaric acid and $50 \mu \mathrm{g}$ of protein (enzyme extract). Protein content was determined with BSA as standard (Bradford, 1976). The control set was done, and $\mathrm{p}$-coumaric acid was withdrawn in the same assay mixture. The reaction was initiated by adding $0.2 \mathrm{mM} \mathrm{NAD}(\mathrm{P}) \mathrm{H}$ in the same assay mixture and incubated at $37^{\circ} \mathrm{C}$ for 5 minutes. The activity of NAD(P)H oxidase was recorded at $A_{340 \mathrm{~nm}}$. The enzyme activity was calculated from change of $\mathrm{OD}$ per $\mathrm{g}$ of protein with extinction coefficient of 0.622 $\mathrm{mM}^{-1} \mathrm{~mm}^{-1}$.

Assay of guaiacol peroxidase (EC 1.11.1.7): The enzyme extract was prepared by thoroughly homogenizing the leaf tissues $(1.0 \mathrm{~g})$ in liquid nitrogen followed by $0.1 \mathrm{M}$ potassium phosphate buffer ( $\mathrm{pH} 7.0)$ under cold condition. The homogenate was centrifuged at $12,000 g_{\mathrm{n}}$ at $4^{\circ} \mathrm{C}$ for $15 \mathrm{~min}$. The protein content of the supernatant was concentrated using $80 \%$ ammonium sulphate $\left[\left(\mathrm{NH}_{4}\right)_{2} \mathrm{SO}_{4}\right]$ precipitation followed by dialysis and Iyophilization (Sambrook and Russell, 2001). The protein was measured according to Bradford (1976). The concentrated protein samples were used as sources of enzyme and incubated in an assay mixture containing $0.1 \mathrm{M}$ phosphate buffer ( $\mathrm{pH} 6.5), 1.5 \mathrm{mM} 0$-dianicidine, $0.2 \mathrm{M} \mathrm{H}_{2} \mathrm{O}_{2}, 50 \mu \mathrm{g}$ of protein at $37^{\circ} \mathrm{C}$. The absorbance was recorded at $430 \mathrm{~nm}$ using extinction coefficient of 0 -dianicidine $\left(2.62 \mathrm{mM}^{-1} \mathrm{~mm}^{-1}\right)$. One unit of enzyme activity was determined as the amount of enzyme required changing the absorbance by 0.1 per unit time (Hu et al., 2009).

Assay of ascorbate peroxidase (EC 1.11.1.11): APX activity was determined as described by De Leonardis et al. (2000), by measuring the decrease in absorbance at $290 \mathrm{~nm}$ in a reaction mixture containing $50 \mathrm{mM}$ phosphate buffer $\mathrm{pH}$ 7.0, $500 \mathrm{mM}$ AsA, $1 \mathrm{mM}$ $\mathrm{H}_{2} \mathrm{O}_{2}$ and $100 \mu \mathrm{g}$ of enzyme extract. The extinction coefficient of AsA (2.62 $\left.\mathrm{mM}^{-1} \mathrm{~mm}^{-1}\right)$ was used to calculate the APX activity.

Assay of superoxide dismutase (EC 1.15.1.1): SOD activity was assayed spectrophotometrically 
according to Alonso et al. (2001). Plant samples were homogenized with $50 \mathrm{mM}$ potassium-phosphate buffer $(\mathrm{pH} 7.5)$ and then centrifuged at $20,000 g_{n}$ for 30 minutes, at $4^{\circ} \mathrm{C}$. Supernatant was added to a reaction mixture containing $50 \mathrm{mM}$ phosphate buffer ( $\mathrm{pH} 7.0)$, $13 \mathrm{mM}$ methionine, $75 \mathrm{mM} \mathrm{NBT}, 100 \mathrm{mM}$ EDTA and 2 $\mathrm{mM}$ riboflavin. The total mixture was kept for 10 min under 15-W fluorescent tubes of $40 \mu \mathrm{mol} \mathrm{m}^{-2} \mathrm{~s}^{-1}$ photon flux density. The control set of reaction mixture was kept in the dark. The activity was calculated from the absorbance at $560 \mathrm{~nm}$.

Statistical analysis: All the observations were recorded with three replications $(n=3)$ and data were expressed as mean \pm SE. The statistical analysis was performed with SPSS 10 statistical package (SPSS Inc., Chicago) by one-way ANOVA, taking $p \leq 0.05$ as significant followed by least significance difference (LSD) test taking $p \leq 0.05$ levels of significance (Gomez and Gomez, 1984).

A
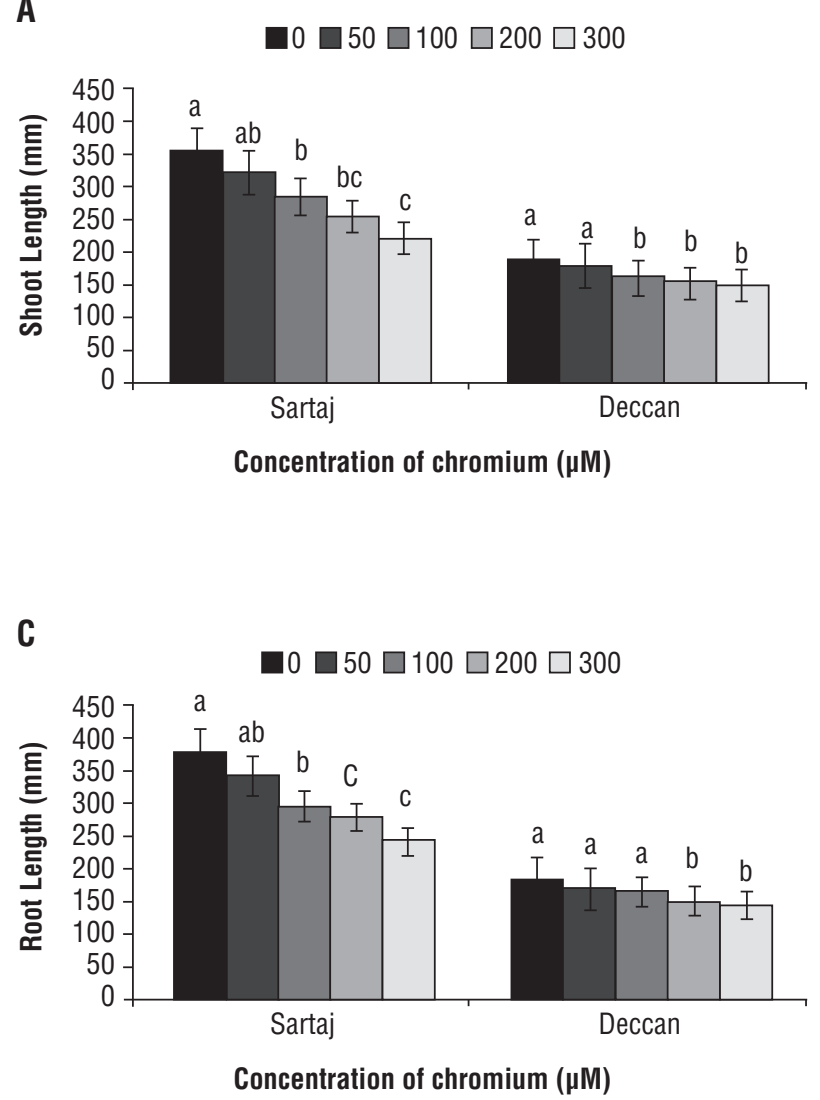

\section{RESULTS}

Plant growth: The oxidative exposure of $\mathrm{Cr}$ and its impact were revealed in the present study for both the varieties. Plants were found to be morphologically weaker in relation to growth and vigor. However, to complete the experiment plants were collected for measurement of length and dry biomass of shoot and root. $\mathrm{Cr}$ exposure significantly inhibited $(p \leq 0.05)$ plant length and biomass (Figure 1). A linear decrease of shoot length (Figure 1A) and dry biomass (Figure 1B) were recorded at different concentrations of $\mathrm{Cr}$. Shoot length was reduced by 37.60 and $19.57 \%$ for varieties Sartaj and Deccan, respectively, at maximum concentration of $\mathrm{Cr}$, i.e. $300 \mu \mathrm{M}$. Shoot biomass also decreased by 59 and $53 \%$ for Sartaj and Deccan at the same maximum concentration. Root length (Figure 1C) and its dry weight (Figure 1D) followed the similar trends of decreasing growth as that recorded in shoot. Root length was decreased by $36 \%$ and $21 \%$ in Sartaj and Deccan. Likewise, the loss of root biomass
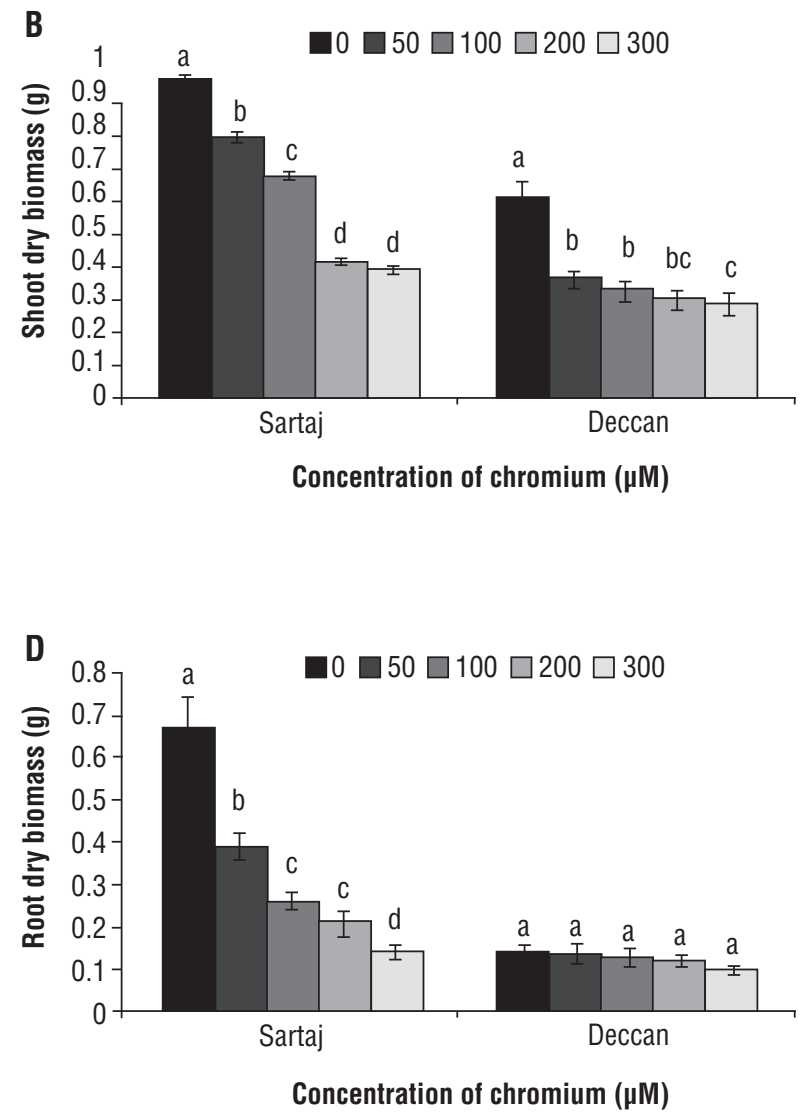

Figure 1. Changes in $(A)$ shoot length, $(B)$ root length, $(C)$ shoot dry biomass, and (D) root dry biomass under different concentrations of $\operatorname{Cr}(\mathrm{VI})(0,50,100,200$ and $300 \mu \mathrm{M})$. Data are mean of three replicates $\pm \mathrm{SE}$, compared to control $(0 \mu \mathrm{M})$ at $\mathrm{p} \leq 0.05$. Different letters indicate significant differences among mean values within each variety (Student $t$-test, $p \leq 0.05$ ). 
was $79 \%$ for Sartaj and $32 \%$ for Deccan at the highest concentration of $\mathrm{Cr}(300 \mu \mathrm{M})$.

Hydrogen peroxide and superoxide radical content: The oxidative stress in plants may be illustrated by showing the accumulation pattern of $\mathrm{O}_{2} \cdot$ (Figure 2 ) and $\mathrm{H}_{2} \mathrm{O}_{2}$ in the tissue (Figure 3). Under each $\mathrm{Cr}$ concentration, the $\mathrm{O}_{2}$ and $\mathrm{H}_{2} \mathrm{O}_{2}$ generation increased significantly $(\mathrm{p} \leq 0.05)$ as compared to those under control condition irrespective of varieties. After seven days of incubation, the variety Sartaj recorded the increase of $\mathrm{O}_{2}-$ by 1.17 fold, 1.33 fold, 1.47 fold, 1.58 fold over control under 50, 100, 200 and $300 \mu \mathrm{M}$ of $\mathrm{Cr}$ salt respectively. Likewise for Deccan, the increase of $\mathrm{O}_{2}-$ under the same concentrations of $\mathrm{Cr}$ was 1.04, 1.29, 1.33 and 1.48 fold respectively. Therefore, Sartaj recorded

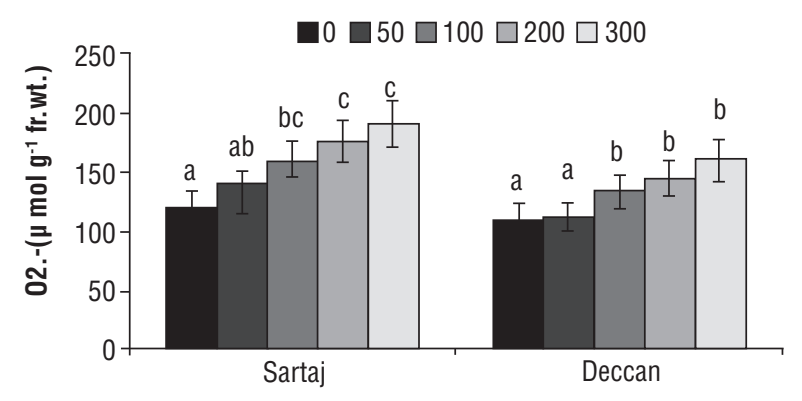

Concentration of chromium $(\mu \mathrm{M})$

Figure 2. Generation of superoxide in Sartaj and Deccan under different concentrations of $\mathrm{Cr}(0,50,100,200$ and $300 \mu \mathrm{M})$. Data are mean of three replicates $\pm \mathrm{SE}$, compared to the control $(0 \mu \mathrm{M})$ at $p \leq 0.05$. Different letters indicate significant differences among mean values within each variety (Student $t$-test, $p \leq 0.05$ ).

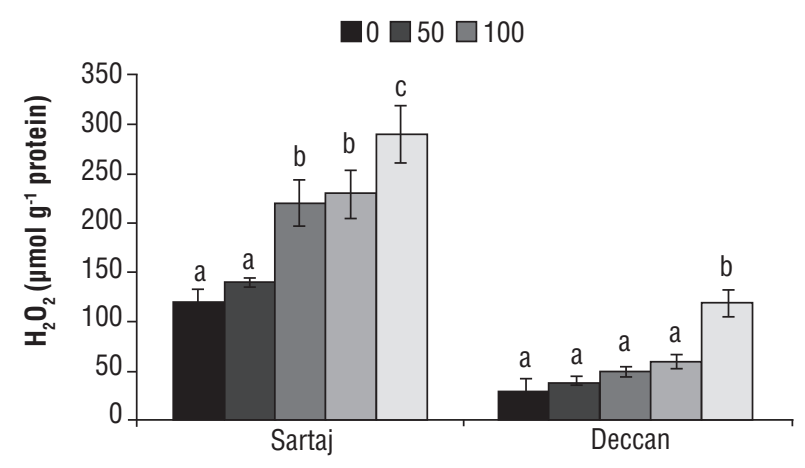

Figure 3. Generation of hydrogen peroxide in Sartaj and Deccan under different concentrations of $\operatorname{Cr}(0,50,100,200$ and 300 $\mu \mathrm{M})$. Data are mean of three replicates $\pm \mathrm{SE}$. Data are mean of three replicates $\pm S E$, compared to the control $(0 \mu \mathrm{M})$ at $p \leq 0.05$. Different letters indicate significant differences among mean values within each variety (Student $t$-test, $\mathrm{p} \leq 0.05$ ). more accumulation of $\mathrm{O}_{2}-$ than variety Deccan uniformly over any concentration of $\mathrm{Cr}$.

Similar findings for $\mathrm{H}_{2} \mathrm{O}_{2}$ accumulation strengthen the evidence for oxidative stress in plants irrespective of varieties. Thus a linear increase in $\mathrm{H}_{2} \mathrm{O}_{2}$ concentration was the feature for both varieties. The $\mathrm{H}_{2} \mathrm{O}_{2}$ content in Sartaj becomes almost 2 and 3 fold for 100 and $300 \mu \mathrm{M}$ of $\mathrm{Cr}$ concentrations, respectively, compared to the control. However, for Deccan accumulation of $\mathrm{H}_{2} \mathrm{O}_{2}$ it was 2 fold at $300 \mu \mathrm{M}$ concentration of $\mathrm{Cr}$ over control.

Malondialdehyde content and protein oxidation: Malondialdehyde and carbonyl contents, measures of lipid peroxidation and protein oxidation respectively, were increased $(p<0.05)$ in both varieties under $\mathrm{Cr}$ stress. For MDA the variety Sartaj proved to be more sensitive in terms of lipid peroxidation by $1.86,2.15,2.39$ and 3.42 fold over control at different concentration of $\mathrm{Cr}$. Deccan recorded 1.4, 1.5, 1.66 and 2.43 fold MDA content over control under those concentration of $\mathrm{Cr}$ (Figure 4).

Similarly, the carbonyl formation was found maximum in Sartaj $(1.06,1.73,3.03$ and 3.34 fold over control respectively for $50,100,200$ and $300 \mu \mathrm{M}$ of $\mathrm{Cr}$ salt), while comparatively lower in Deccan (1.6, 2.15, 2.58 and 3.66 fold over control respectively for the same concentration of $\mathrm{Cr}$ salt) (Figure 5).

Estimation of $\mathrm{NAD}(\mathrm{P}) \mathrm{H}$ oxidase: One of the source of ROS at cellular level is furnished by the oxidation of $\mathrm{NAD}(\mathrm{P}) \mathrm{H}$ in intercellular spaces by membrane bound $\mathrm{NAD}(\mathrm{P}) \mathrm{H}$ oxidase activity, because $\mathrm{NAD}(\mathrm{P}) \mathrm{H}$ oxidase

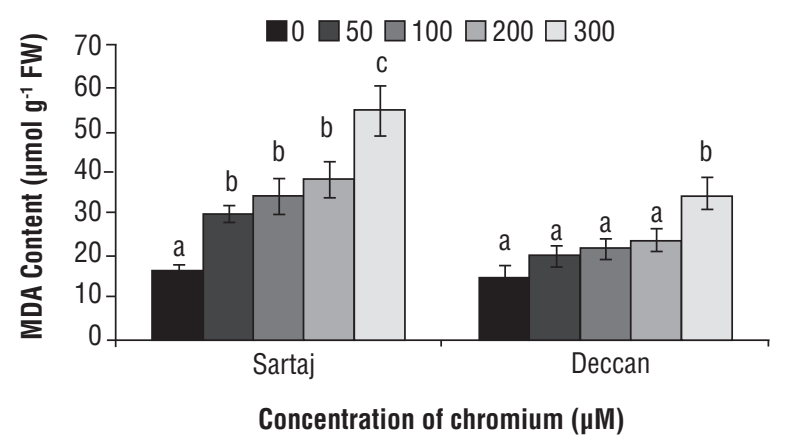

Figure 4. Malondialdehyde (MDA) content of Sartaj and Deccan under different concentrations of $\operatorname{Cr}(0,50,100,200$ and 300 $\mu \mathrm{M})$. Data are mean of three replicates $\pm \mathrm{SE}$, compared to the control $(0 \mu \mathrm{M})$ at $p \leq 0.05$. Different letters indicate significant differences among mean values within each variety (Student $t$-test, $\mathrm{p} \leq 0.05)$. 
transfers electrons from $\mathrm{NAD}(\mathrm{P}) \mathrm{H}$ to $\mathrm{O}_{2}$ to form superoxide radical $\left(\mathrm{O}_{2}^{-}\right)$. Thus, in the present studies plants were found to upregulate the $\mathrm{NAD}(\mathrm{P}) \mathrm{H}$ oxidase activity by varying concentration of $\mathrm{Cr}$ (Figure 6). The activity increased by 1.02, 1.18, 1.26 and 1.3 fold in variety Sartaj, whereas those were 1.04, 1.05, 1.14 and 1.17 fold in the case of Deccan. On comparative basis, Sartaj was recorded 1.35 fold higher than Deccan at the highest concentration of $\mathrm{Cr}$.

Estimation of antioxidative enzymes: The antioxidative responses of those varieties in terms of enzymes like SOD, guaiacol peroxidase (GPX), and

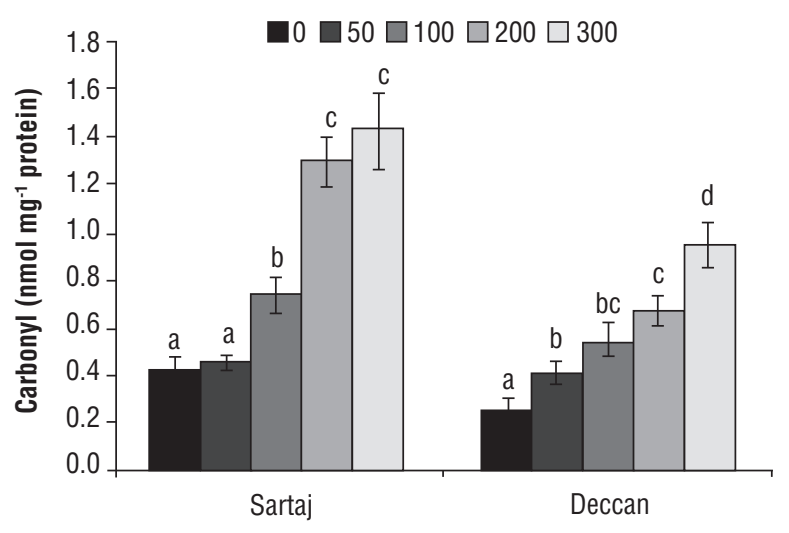

Figure 5. Protein carbonyl content of Sartaj and Deccan under different concentrations of $\mathrm{Cr}(0,50,100,200$ and $300 \mu \mathrm{M})$. Data are mean of three replicates $\pm \mathrm{SE}$, compared to the control $(0 \mu \mathrm{M})$ at $p \leq 0.05$. Different letters indicate significant differences among mean values within each variety (Student $t$-test, $\mathrm{p} \leq 0.05$ ).

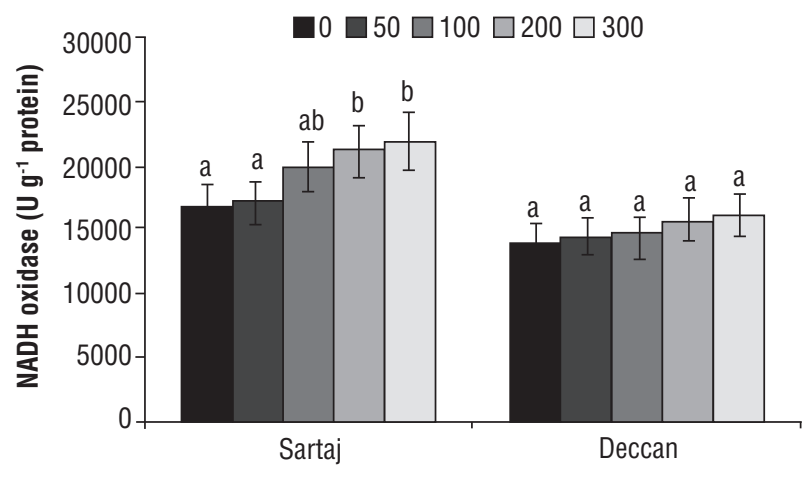

Figure 6. Changes in $\mathrm{NAD}(\mathrm{P}) \mathrm{H}$ oxidase content of Sartaj and Deccan under different concentrations of chromium $(0,50$, $100,200$ and $300 \mu \mathrm{M})$. Data are mean of three replicates \pm $\mathrm{SE}$, compared to the control $(0 \mu \mathrm{M})$ at $p \leq 0.05$. Different letters indicate significant differences among mean values within each variety (Student $t$-test, $\mathrm{p} \leq 0.05$ ).
APX showed significant $(p \leq 0.05)$ variation to $C r$. The GPX activity was at maximum in Sartaj, with records of 1.08, 1.23, 1.88 and 1.96 fold over control (Figure 7). Deccan showed similar trends of GPX activity, i.e., $1.05,1.25,1.75$ and 1.96 fold over control at different concentrations of $\mathrm{Cr}$. The APX activity was also increased in both varieties under treatment. In comparison, the level of APX was higher in Sartaj $(1.04,1.08,1.12$ and 1.16 fold over control) than Deccan $(1.01,1.04,1.08$ and 1.16 fold over control) at every concentration of $\mathrm{Cr}$ (Figure 8). On the other hand, the SOD activity was stimulated in response to $\mathrm{Cr}$. The trend of SOD activity was almost similar in two varieties, differing at most at $300 \mu \mathrm{M}$ of $\mathrm{Cr}$ (Figure 9). It recorded 1.38, 2.0, 3.6 and 4.85 fold higher than the control in Sartaj, whereas 1.54 , $2.18,3.82$ and 5.36 fold over control in Deccan.

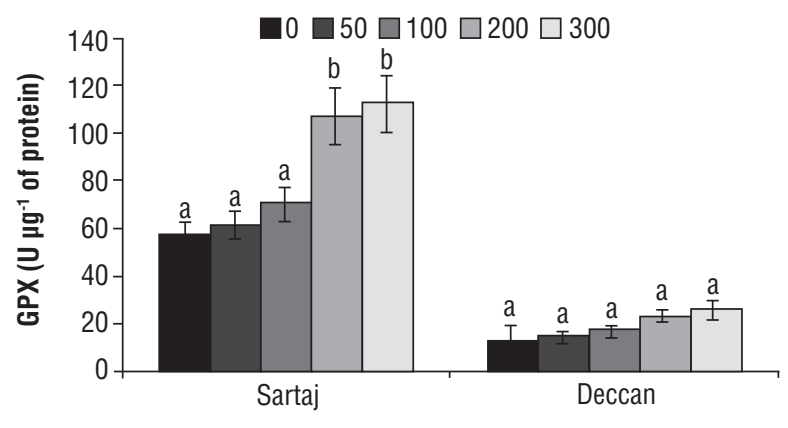

Figure 7. Assay of guaiacol peroxidase in Sartaj and Deccan under different concentrations of chromium $(0,50,100,200$ and $300 \mu \mathrm{M})$. Data are mean of three replicates $\pm \mathrm{SE}$, compared to the control $(0 \mu \mathrm{M})$ at $p \leq 0.05$. Different letters indicate significant differences among mean values within each variety (Student $t$-test, $p \leq 0.05$ ).

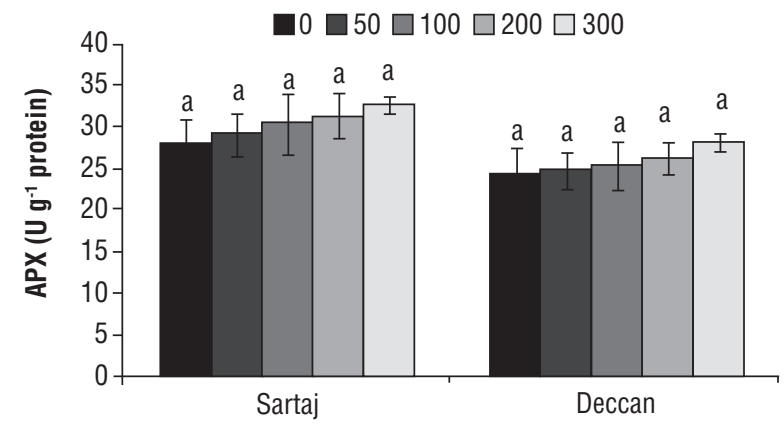

Figure 8. Assay of ascorbate peroxidase in Sartaj and Deccan under different concentrations of chromium $(0,50,100,200$ and $300 \mu \mathrm{M})$. Data are mean of three replicates $\pm \mathrm{SE}$, compared to the control $(0 \mu \mathrm{M})$ at $p \leq 0.05$. Different letters indicate significant differences among mean values within each variety (Student $t$-test, $p \leq 0.05$ ). 


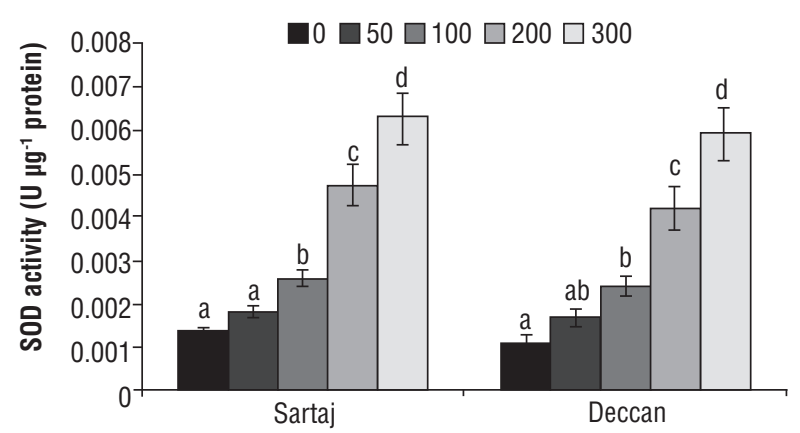

Figure 9. Assay of superoxide dismutase in Sartaj and Deccan under different concentrations of $\mathrm{Cr}(0,50,100,200$ and $300 \mu \mathrm{M})$. Data are mean of three replicates $\pm \mathrm{SE}$, compared to the control $(0 \mu \mathrm{M})$ at $p \leq 0.05$. Different letters indicate significant differences among mean values within each variety (Student t-test, $p \leq 0.05$ ).

\section{DISCUSSION}

The present investigation aimed at evaluating the physiological and cellular performances of two maize varieties under different concentrations of $\mathrm{Cr}$. Maize plants have been found to significantly suffer under $\mathrm{Cr}$ treatments, especially as to root growth and biomass. A distinct reduction in root growth as well as in allied attributes has been documented in the results section. The changes of root growth extrapolate in succession to the other phytotoxic symptoms on shoot under $\mathrm{Cr}$ contamination (Liu et al., 2008). In general, Cr-induced alteration of physiological activities in all plants starts with disease development and malfunctioning of root physiology (Dhir et al., 2009), which is manifested, to impair photosynthetic activities, water relation, translocation of organic solutes and so on as reported in cereal crop (Panda, 2007). Oxidative stress caused by $\mathrm{Cr}$ or other heavy metals as a severe phytotoxicity in every possible way limit successful plants growth and development. Moreover, treatments with $\mathrm{Cr}$ salt had recorded in dose response the inhibition of seedling growth leaf development, proper pigment and its functioning, etc. (Panda and Choudhury, 2005). At cellular level, the uptake of $\mathrm{Cr}$ in excess has been more inductive to oxidative stress by generation of ROS (Wang et al., 2010). Therefore, the uptake of $\mathrm{Cr}$ being mainly facilitated by specific membrane transporter, generation of ROS and its impact on the membrane should have more attention. Plants under normal physiological conditions can accommodate ROS produced in different cellular compartments harbouring electron transport chain. Those include cell wall, apoplastic space, plasma membrane, chloroplast, mitochondria etc. But the production of ROS beyond the capacity of cells may create the oxidative damage (Dhir et al., 2009).

In the present experiment, a significant rise of $\mathrm{O}_{2}^{-}$and $\mathrm{H}_{2} \mathrm{O}_{2}$, regardless of varieties, is interesting to notice. It could be considered as a preliminary outcome of oxidative induction. $\mathrm{H}_{2} \mathrm{O}_{2}$, by nature being not a typical radical, still, very often is regarded to be safe within the threshold level of tissue. Thus, with lower concentration of $\mathrm{Cr}$ both the varieties tended to minimize the $\mathrm{H}_{2} \mathrm{O}_{2}$ level, but peaked at $300 \mu \mathrm{M}$ of $\mathrm{Cr}$. Hydrogen peroxide may act as a secondary messenger to trigger many physiological processes, as recorded under various biotic and abiotic stress. Inhibition of root cell by application of $\mathrm{Cr}$ had been reported by Arora et al. (2006) with moderate increase in $\mathrm{H}_{2} \mathrm{O}_{2}$ content. On the other hand, since $\mathrm{O}_{2}$ - is more reactive, unstable and impermeable to biological membrane, it reacts with $\mathrm{H}_{2} \mathrm{O}_{2}$ to generate hydroxyl radicals. The latter, being the most potent ROS, plays a major role in membrane lipid peroxidation. The exposure exposure of $\mathrm{Cr}$ undoubtedly accelerates the oxidative damage in crop plants in natural environmental conditions by inducing lipid peroxidation (Dhindsa et al., 1981). Regarding the source of $\mathrm{O}_{2}-$ and other ROS generation, there is some oxidase located in apoplastic spaces and ionically bound cell wall polymers, or even cell membrane bound becoming over activated. In the present experiment, $\mathrm{NAD}(\mathrm{P}) \mathrm{H}$ oxidase mediates the oxidation of $\mathrm{NADH}$ with simultaneous reduction of $\mathrm{O}_{2}$ to $\mathrm{O}_{2}^{-}$and $\mathrm{H}_{2} \mathrm{O}_{2}$. This oxidase activity has a significant sharing in generation of oxidative bust with other membrane bound peroxidises and oxidases (Achary et al., 2007). $\mathrm{Cr}$ and other heavy metals are mostly observed with a significant expression of NADH oxidases activity in many plant species. Moreover, the variation in activities between the two varieties (Sartaj and Decan) is one more confirmation of oxidative stress under $\mathrm{Cr}$ induction. The variation in $\mathrm{NAD}(\mathrm{P}) \mathrm{H}$ oxidase activity could be regarded as discriminatory sensitivity of oxidative stress in terms of the same enzyme activity, as reported earlier (Sharma et al., 2012), under heavy metal stress. Meanwhile, the exposure to redox metals (in this case, the $\mathrm{Cr}$ ) could be able to induce the ROS by Fenton type and other redox types of reaction. On the other hand, the impact of oxidative stress on plants could easily be justified through its lipid peroxidation and protein oxidation level. 
This is considered as a consequence of ROS imposed lipid peroxidation of cell membrane and other organelles (Ghosh et al., 2011). The level of MDA content recorded to induce differences between the two varieties is suggestive to their differential sensitivity to oxidative stress. Lipid peroxidation happens to be a crucial effect of ROS, where a chain of reactions are operated with different intermediates at successive levels of peroxidation. The physical structure of plant cell membrane is placing the fatty acid side chains in close proximity. Thereby, it enables the autocatalytic process in consecutive stress. Initially, lipids in the membrane are converted into alkaline radicals. In the propagation steps, it is converted into hydroperoxides, epoxide. Finally, fatty acids are produced and complete lipid peroxidation (Bhattacharjee, 2005). This is followed by an irreversible oxidation of protein moieties, and that turns over some carbonylated derivatives. Metal ions with strong redox potential ( $\mathrm{Cr}$ being one of those) accelerate the the membrane peroxidation more rapidly than other non-redox metals (Dhir et al., 2009).

The accumulation of $\mathrm{Cr}$ in plant tissues happens in order to induce the alteration of metabolic reaction of plants with up or down regulation of enzymatic cascade. The antioxidative enzymes tolerant to $\mathrm{Cr}$ induced oxidative stress recorded a similar response. With the illustration of peroxidase activity taken both guaiacol and ascorbate as phenolic substances, plants were induced according to concentrations of $\mathrm{Cr}$. Peroxidases in plants are commonly referred as monomeric heme containing enzymes which are able to catalize the reactions with phenolic moieties as electron donor to reduce $\mathrm{H}_{2} \mathrm{O}_{2}$ into $\mathrm{H}_{2} \mathrm{O}$. The hyperactivity of peroxidase under $\mathrm{Cr}$ contaminated waste water in many aquatic plants has been implicated as constant detoxification of $\mathrm{H}_{2} \mathrm{O}_{2}$. Our results are in conformity with earlier studies on upregulation of antioxidative enzymes under heavy metal (Shanker et al., 2005). Peroxidase is attributed to lignifications by the cross linking of phenolic residues in the cell wall matrix. This is probably forwarded for the rigidity of cell wall or shielding the membrane from peroxidation under the condition of metal stress (Bhattacharjee, 2005).

Likewise, APX enzyme is displayed with its variable isozymic forms for antioxidation processes of $\mathrm{H}_{2} \mathrm{O}_{2}$. In most cases, APX is responsible for such activities with cytosolic, chloroplastic, mitochondrial and other organelle under various metal stresses (Hu et al., 2007). Notably, in the present experiment the variety
Deccan recorded the highest activity only at $300 \mu \mathrm{M} \mathrm{Cr}$ concentration, whereas Sartaj recorded a steady linear increase against the increasing $\mathrm{Cr}$ concentrations. Two varieties showed discriminatory responses of APX to $\mathrm{H}_{2} \mathrm{O}_{2}$. To be more specific, APX is supposed to be less involved in $\mathrm{H}_{2} \mathrm{O}_{2}$ detoxification rather than the regulation of $\mathrm{H}_{2} \mathrm{O}_{2}$ as a signalling molecule (Cuypers et al., 2011). SOD is furnished with first line of defense, where $\mathrm{O}_{2}$ is dismuted in $\mathrm{H}_{2} \mathrm{O}_{2}$ and $\mathrm{O}_{2}$. The accumulation of $\mathrm{O}_{2}$. or other free radicals in general could be detoxified by SOD. Cr, like other heavy metals, is quite efficient to induce SOD to detoxify the effect of $\mathrm{O}_{2}-$. However, a discriminatory pattern is also reported in many studies. Those findings are coordinated with variation of metal concentrations, duration of exposure, tissue types and even the valence of metals (Tanaka et al., 1996). Whatever the cases might be, the elevation of SOD activity in general is a clear indication to detoxify the $\mathrm{O}_{2}{ }^{-}$and other ROS in downstream pathways in different cell organelle under metal stress. The two varieties in the present experiment established their differential antioxidation pathway under the same concentration of $\mathrm{Cr}$. However, Sartaj proved to be more efficient in this process.

Conclusively, the present experiment showed that the bioaccumulation of $\mathrm{Cr}$ had significantly affected the maize with reference to oxidative stress. $\mathrm{Cr}$, for being a hazardous redox metal, has significantly curtailed root growth and biomass accumulation along with oxidative damage of cell membrane. Out of the two varieties, Deccan was more potential to minimize the lipid peroxidation and protein oxidation than Sartaj. On that basis, the former variety is likely to be more tolerant than the latter. So, the accumulation of ROS could induce the antioxidation pathway with regards to those enzymes, like SOD, GPX and APX. From the overall responses of varieties, the sensitivity of the oxidative stress is likely to be correlated with the antioxidation capacity directly. Admittedly, a short term effect of metal stress under in vitro condition may not necessarily be a reflection of behaviour of plants as compared to prolonged metal stress in field. Still, the findings could help to assess the survival of the plants at seedling stage. Maize is a $\mathrm{C}_{4}$ plant and is well adaptive to water stress through its modified carbon metabolism, which may lead to improved antioxdation pathways. So, future scope still remains to study other aspects of antioxidation pathways, which could be reliable indexes in selection for $\mathrm{C}_{4}$ plants under Cr stress. 
Acknowledgments: The work was supported by the DST-FIST programme, DST, Governemnt of India, New Delhi. Department of seed science, Bidhan Chandra Krishi Viswavidyalaya, Mohanpur, West Bengal, India is duly acknowledged for providing the maize seeds.

\section{REFERENCES}

Achary VM, Jena S, Panda KK, Panda BB (2008) Aluminium induced oxidative stress and DNA damage in root cells of Allium cepa L. Ecotoxicol. Environ. Saf. 70:300-310.

Alonso R, Elvira S, Castillo FJ, Gimeno BS (2001) Interactive effects of ozone and drought stress on pigments and activities of antioxidative enzymes in pinus halepensis. Plant Cell Environ. 24:905-916.

Arora A, Saxena S, Sharma DK (2006) Tolerance and phytoaccumulation of chromium by three Azolla species. World J. Microbiol. Biotechnol. 22:97-100.

Bradford MM (1976) A rapid and sensitive method for the quantitation of microgram quantities of protein utilizing the principle of protein-dye binding. Anal. Biochem. 72:248-254.

Bhattacharjee S (2005) Reactive oxidative species and oxidative stress in plants: roles in stress, senescence and signal transduction in plants. Curr. Sci. 89:1113-1121.

Cuypers A, Smeets K, Ruytinx J, Opdenakker K, Keunen E, Remans T, Horemans N, Vanhoudt N, Van Sanden S, Van Belleghem F, Guisez Y, Colpaert J,Vangronsveld J (2011) The cellular redox state as a modulator in cadmium and copper responses in Arabidopsis thaliana seedlings. J. Plant Physiol. 168:309-316.

De Leonardis S, Dipierro N, Dipierro S (2000) Purification and characterization of an ascorbate peroxidase from potato tuber mitochondria. Plant Physiol. Biochem. 38:773-779.

Dhindsa RS, Plumb-Dhindsa P, Thorpe TA (1981) Leaf senescence: correlated with increased levels of membrane permeability and lipid peroxidation, and decreased levels of superoxide dismutase and catalase. J. Exp. Bot. 32:93-101.

Dhir B, Sharmila P, Pardha Saradhi P, Nasim SA (2009) Physiological and antioxidant responses of Salvinia natans exposed to chromium-rich wastewater. Ecotoxicol. Environ. Saf. 72:1790-1797.

Elstner EF, Heupel A (1976) Inhibition of nitrite formation from hydroxylammoniumchloride: a simple assay for superoxide dismutase. Anal. Biochem. 70:616-620.

Emsley J (2001) “Chromium”. Nature's Building Blocks. In: An AZ Guide to the Elements, pp.495-498. Oxford University Press, Oxford, England.

Gomez KA, Gomez AA (1984) Statistical Procedures for Agricultural Research. Wiley, New York.

Gratão PL, Polle A, Lea PJ, Azevedo RA (2005) Making the life of heavy metal-stressed plants a little easier. Funct. Plant Biol. 32:481-494.

Gikas P, Romanos P (2006) Effects of trivalent (Cr (III)) and hexa-valent $(\mathrm{Cr}(\mathrm{VI}))$ chromium on the growth of activated sludge. J. Hazard Mater. 133:212-217

Ghosh N, Adak MK, Ghosh PD, Gupta S, Sen Gupta DN, Mandal C (2011) Differential responses of two rice varieties to salt stress. Plant Biotechnol. Rep. 5:89-103.
Hoagland D, Arnon DI (1950) The water culture method for growing plants without soil, College of Agriculture, University of California, Berkeley, CA, USA. Calif. Agr. Expt. Sta. Cir. 347:1-32.

Heath RL, Packer L (1968) Photoperoxidation in isolated chloroplasts. I. Kinetics and stoichiometry of fatty acid peroxidation. Arch. Biochem. Biophys. 125:189-198.

Hu Y, Ge Y, Zang C, Zu T, Cheng W (2009) Cadmium toxicity and translocation in rice seedlings are reduced by hydrogen peroxide treatments. Plant Growth Regul. 5:51-61.

Hu C, Zheng L, Hamilton D, Zhou W, Yang T, Zhu D (2007) Physiological responses induced by copper bioaccumulation in Eichhornia crassipes. Hydrobiologia 579:211-218.

Kotás J, Stasicka Z (2000) Chromium occurrence in the environment and methods of its speciation. Environ. Pollut. 107:263-283.

Liu D, Zou J, Wang M, Jiang W (2008) Hexavalent chromium uptake and its effects on mineral uptake, antioxidant defense system and photosynthesis in Amaranthus viridis L. Bioresourc. Technol. 99:2628-2636.

Pandey N, Sharma CP (2003) Chromium interference in iron nutrition and water relations of cabbage. Environ. Exp. Bot. 49:195-200.

Panda SK, Choudhury S (2005) Chromium stress in plants. Braz. J. Plant Physiol. 17:95-102.

Panda SK (2007) Chromium-mediated oxidative stress and ultrastructural changes in root cells of developing rice seedlings. J. Plant Physiol. 164:1419-1428.

Sambrook J, Russell DW (2001) Molecular cloning: a laboratory manual. Cold Spring Harbor Laboratory Press, Cold Spring Harbor, New York, USA.

Shanker AK, Djanaguiraman M, Sudhagar R, Chandrashekar CN, Pathmanabhan $\mathrm{G}$ (2004) Differential antioxidative response of ascorbate glutathione pathway enzymes and metabolites to chromium speciation stress in green gram (Vigna radiata (L.) R. Wilczek. $\mathrm{Cv} \mathrm{CO}_{4}$ ) roots. Plant Sci. 166:1035-1043.

Shanker AK, Cervantes C, Loza-Tavera H, Avudainayagam S (2005) Chromium toxicity in plants. Environ. Int. 31:739-753.

Sharma P, Jha AB, Dubey RS, Pessarakli M (2012) Reactive oxygen species, oxidative damage, and antioxidative defense mechanism in plants under stressful conditions. J. Bot. doi:10.1155/2012/217037.

Smiri M, Chaoui A, Rouhier N, Gelhaye E, Jacquot JP, El Ferjani E (2010) NAD pattern and NADH oxidase activity in pea (Pisum sativum L.) under cadmium toxicity. Physiol. Mol. Biol. Plants 16:305-315.

Sun X, Yuan S, Lin HH (2006) Salicylic acid decreases the levels of dehydrin-like proteins in Tibetan hulless barley leaves under water stress. Z. Naturforsch. C 61:245-250.

Tanaka K, Takio S, Yamamoto I, Satoh T (1996) Purification of the cytosolic CuZn-superoxide dismutase (CuZn-SOD) of Marchantia paleacea var. diptera and its resemblance to CuZn-SOD from chloroplasts. Plant Cell Physiol. 37:523-529.

Uma MS, Viswanath DP, Rao MRG, Chimmad VP (1990) Salt tolerance of some maize genotypes. Crop Improvement 17:22-26.

Vajpayee P, Tripathi RD, Rai UN, Ali MB, Singh SN (2000) Chromium (VI) accumulation reduces chlorophyll biosynthesis, nitrate reductase activity and protein content in Nymphaea alba L. Chemosphere 41:1075-1082. 
Verbeke P, Siboska GE, Clark BF, Rattan SI (2000) Kinetin inhibits protein oxidation and glycoxidation in vitro. Biochem. Bioph. Res. Commun. 276:1265-1270.

Wang BJ, Sheu HM, Guo YL, Lee YH, Lai CS, Pan MH, Wang YJ (2010) Hexavalent chromium induced ROS formation, Akt, NF-kappaB, and MAPK activation, and TNF-alpha and IL-1alpha production in keratinocytes. Toxicol. Lett. 198:216-224.
Zou J, Yu K, Zhang Z, Jiang W, Liu D (2009) Antioxidant response system and chlorophyll fluorescence in chromium (VI)-treated Zea mays (L.) seedlings. Acta Biol. Cracov. Bot. 51:23-33.

Zou J, Wang M, Jiang W, Liu D (2006) Chromium accumulation and its effects on other mineral elements in Amaranthus viridis L. Acta. Biol. Cracov. Bot. 48:7-12. 